\title{
Development and evaluation of a Planktonic Integrity Index (PII) for Jingpo Lake, China
}

\author{
Xing WANG, ${ }^{1,2}$ Yan LIU, ${ }^{1,2}$ Xueyan YIN, ${ }^{1,2}$ Xingru ZHAO, ${ }^{1,2}$ Rui GUO,,${ }^{1,2}$ Binghui ZHENG ${ }^{1,2 *}$ \\ ${ }^{1}$ National Engineering Laboratory for Lake Pollution Control and Ecological Restoration, Chinese Research Academy of \\ Environmental Sciences, Beijing 100012; ${ }^{2}$ State Environmental Protection Key Laboratory of Drinking Water Source Protection, \\ Chinese Research Academy of Environmental Sciences, Beijing 100012, China
}

\begin{abstract}
A Planktonic Integrity Index (PII) for the China's largest alpine barrier lake (Jingpo Lake) was developed to assess the water quality of Jingpo Lake by using phytoplankton and zooplankton metrics. Phytoplankton and zooplankton assemblages were sampled at 26 sites in Jingpo Lake. A total of 140 species of phytoplankton and 92 species of zooplankton were obtained in the investigations. We used a stepwise process to evaluate properties of candidate metrics and selected five for the PII: Algal cell abundance, Species richness of algae, Trophic diatom index, Zooplankton Shannon index, and Zooplankton Margalef index. Evaluation of the PII showed that it discriminated well between reference and impaired sites and the discriminatory biocriteria of the PII were suitable for the assessment of the water quality of Jingpo Lake. The further scoring results from the 26 sites showed that the water quality of Jingpo Lake was fair to good. The results of analyses between PII and major environmental factors indicated that water temperature (WT), transparency (SD), dissolved oxygen (DO), potassium permanganate $\left(\mathrm{COD}_{\mathrm{Mn}}\right)$ and total nitrogen $(\mathrm{TN})$ were the main factors influencing on the composition and distribution of phytoplankton and zooplankton. Additionally, more metrics belonging to habitat, hydrology, physics and chemistry should be considered for the PII, so as to establish comprehensive assessment system which can reflect the community structure of aquatic organisms, physical and chemical characteristics of water environment, human activities, etc.
\end{abstract}

\section{INTRODUCTION}

As primary producers at the beginning of the food chain in aquatic ecosystem, phytoplankton have the characteristics of short life cycle are sensitive to pollution, and their community structure can transform along with the changes in water chemistry. Phytoplankton are also amongst the most widely used indicators of biological integrity and physicochemical conditions in aquatic ecosystems (Hill et al., 2003; Miller et al., 2006; Zalack et al., 2010; Wu et al., 2012b). Zooplankton, as the second trophic level of the food webs in aquatic ecosystem, play a vital role in ecological processes of material transformation and energy flow. Further their community

Corresponding author: happyhundan@tom.com

Keywords: Phytoplankton; zooplankton; metrics; bioassessment; water quality; Jingpo Lake.

Edited by: Federico Marrone, University of Palermo, Italy

Received: 7 September 2018

Accepted: 17 Janaury 2019.

This work is licensed under a Creative Commons Attribution NonCommercial 4.0 License (CC BY-NC 4.0).

CCopyright X. Wang et al., 2019

Licensee PAGEPress, Italy

J. Limnol., 2019; 78(1): 135-146

DOI: 10.4081/jlimnol.2019.1855 structure, abundance, dominant taxa, and pollution indicator species are widely used to reflect the water status (Swadling et al., 2000; Echaniz et al., 2006; Jiang et al., 2012). Since 1990 s, the water quality bioassessment by using single biotic metrics began to be displaced by the integrated water quality bioassessment based on multiple metric (Kerans and Karr, 1994; Blocksom et al., 2002; Lugoli et al., 2012). However, there are several problems in the actual operation and assessment as followed: i) the growth of aquatic organisms is influenced by not only water quality but also parameters of physics, chemistry, climate, hydrology and so on, increasing the random errors of sampling; ii) the precision of identification of specimens may affect the accuracy of bioassessment; iii) the bio-metrics based on one assemblage can only represent one aspect of the communities and functions in ecosystem, or respond to limited stressors, which may also affect the accuracy of bioassessment for water quality (Wang et al., 2015c). Therefore, the use of at least two assemblages has been suggested for more robust biological assessment of condition, as each assemblage may respond differently to potential stressors (Yoder and Rankin, 1995). Multi-biotic indicators and metrics for fish, phytoplankton, zooplankton, or macroinvertebrate assemblage condition have been developed for streams (Angermeier et al., 2000; McCormick et al., 2001; Klemm et al., 2003; Whittier et al., 2007; Chon et al., 2013) and lakes (O'Connor et al., 2000; Wilcox et al., 2002; Kane et al., 2009; Wang et al., 2015c). However, there are still some inadequacies in the present multiassemblage assessment. For example, the subjectivity of 
the choice of metrics, and the lack of rigorous screening based on discrimination and redundancy of the chosen metrics, leading to some alternative metrics being left off during the development of the multi-metric index. So far, multi-assemblage assessment has just been used for Chinese lakes, that is why we need to establish a multimetric index based on multi-assemblages to assess the water quality of the lakes in China. Such an index should be able to reflect to a variety of potential stressors. Jingpo Lake is the largest alpine barrier lake of China, which located at $\mathrm{N} 43^{\circ} 30^{\prime}-44^{\circ} 20^{\prime}$ and $\mathrm{E} 128^{\circ} 07^{\prime}-129^{\circ} 06^{\prime}$ in Ningan country of Heilongjiang province. As a nature reservoir belonging to Mudanjiang River, Jingpo Lake contains the storage capacity of 1.6 billion $\mathrm{m}^{3}$, the annual average impoundage of 1.1 billion $\mathrm{m}^{3}$, the basin area of $11,820 \mathrm{~km}^{2}$, the scenic spot area of $1,726 \mathrm{~km}^{2}$, the nature reserve area of $1260 \mathrm{~km}^{2}$, and the average lake area of $79.3 \mathrm{~km}^{2}$ (Chen et al., 1994). Jingpo Lake plays an important role in freshwater aquaculture, tourism, electricity, transportation, drinking water sources. However, in the past few years, environment pollutions of the Jingpo Lake have become more and more serious because of development of agriculture and fisheries, land use changes, industrial pollutants etc. These pollutants have caused the gradual reduction of species, abundance, and diversity of phytoplankton and zooplankton (Yu et al., 2008b; Song and Yu, 2009; Liu et al., 2012, Wang et al., 2015a, 2015b). In this study, we developed and tested the Planktonic Integrity Index (PII) using a training data set and a testing data set of phytoplankton and zooplankton, respectively, from Jingpo Lake. Our specific objectives were to: i) develop a PII based on phytoplankton and zooplankton metrics, so as to create an offshore water quality monitoring tool that reflected Beneficial Use Impairments to Jingpo Lake and would be generally applicable to other lakes in China; ii) deduce the water quality of the study area by implementing the developed PII; iii) test the accuracy of the PII index by its relationship with local physical-chemical parameters.

\section{METHODS}

\section{Study area}

Jingpo Lake has a maximum length of $45 \mathrm{~km}(\mathrm{~N}-\mathrm{S})$, width of $6 \mathrm{~km}(\mathrm{E}-\mathrm{W})$, is shallow at its southern and deep at the northern part. It has an average depth of $13.8 \mathrm{~m}$ and a maximum depth of $70 \mathrm{~m}$. The annual average influx of water is $90.8 \mathrm{~m}^{3}$ per second and runoff of 2.87 billion $\mathrm{m}^{3}$. The study area lies in a temperature zone with annual average temperature of $4.3^{\circ} \mathrm{C}$ its climate belongs to monsoon climate zone with long cold winters and short cool summers, with annual average relative humidity of $71.5 \%$, precipitation of $619.8 \mathrm{~mm}(\mathrm{Li}$,
2013). The study area consists of 26 sample sites located throughout Jingpo Lake (Fig. 1). In detail, S1 represents the water quality of inflowing water from Jilin Province; S2 to S6 represents the water quality of Xidapao, Dongdapao, Big-Little Jiaji River and Songyi River, respectively; S7 to S11 represents the water quality of upstream of Jingpo Lake; S12 and S13 represents the water quality of the entrance from Erzhan River to Jingpo Lake and inflowing water from upstream of Erzhan River, respectively; S14 to S22 represents the water quality of lake region; S23 and S24 represents the water quality of Jingpo mount and inflowing water from Baoyue Bay; S25 represents the water quality of out-water of Jingpo Lake; S26 represents the water quality of inflowing water from Ziling Lake.

\section{Sampling and processing of phytoplankton and zooplankton}

Phytoplankton was sampled and concentrated by a $25-$ micron mesh through the entire water column (from the bottom to the top) in September and October of 2013. Collected organisms were stored in 5\% non-acetic Lugol's iodine solution. Non-diatom phytoplankton was

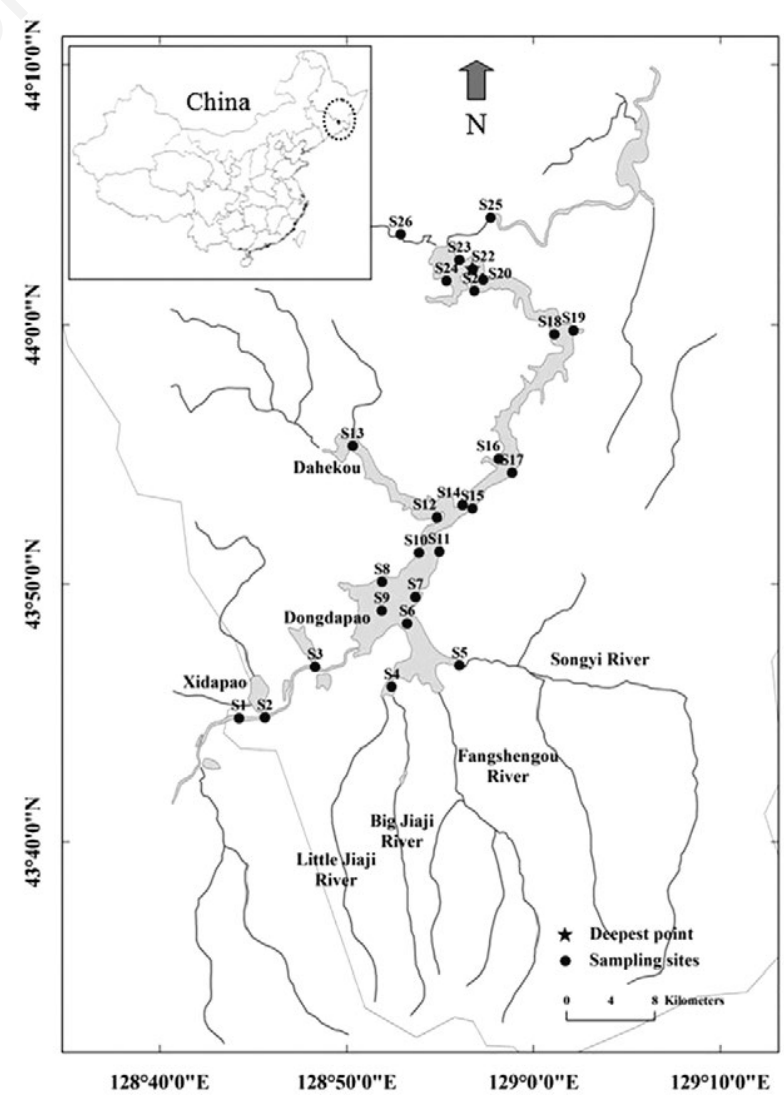

Fig. 1. Sampling sites of Jingpo Lake in 2013. 
analyzed using a $0.1 \mathrm{~mL}$ counting chamber at a magnification of 400× (Zeiss Axioskop microscope). Permanent diatom samples were cleaned using a strong acid solution $\left(\mathrm{HNO}_{3}+\mathrm{H}_{2} \mathrm{SO}_{4} ; 2: 1\right)$. From each sample, about 500 valves were counted for each sample using a Zeiss Axioskop microscope at 1000× under oil immersion. Phytoplankton was identified to the lowest taxonomic level possible (mainly species level) and its densities were expressed as cell $\mathrm{L}^{-1}$ (Wu et al., 2012a).

Zooplankton at each site was sampled with a Wisconsin net (mesh size: $50 \mu \mathrm{m}$; mouth diameter: $25 \mathrm{~cm}$ ) that was towed through the water column, during the same sampling event as phytoplankton. Each catch was preserved in $4 \%$ formaldehyde and kept refrigerated until further work. Zooplankton was identified to the lowest taxon level possible, usually to species level. Copepod nauplii could not be identified as calanoid or cyclopoid and were pooled. If the number of individuals in a sample was less than 1500 the entire catch was sorted, otherwise it was split so that between 1000 and 1500 organisms were counted. The number of zooplankton cells in each species or genus was calculated by determining the cells collected at each site and converted to cell L-1 (Swadling et al., 2000).

\section{Water quality measures and characterization of reference and impaired sites}

Water quality samples were collected and composited at the same time and locations as phytoplankton and zooplankton samples. For each sampling site, in situ measurements included conductivity (EC), $\mathrm{pH}$, dissolved oxygen (DO), and water temperature (WT), whose values were averaged from two depths $(0.5 \mathrm{~m}$ below the surface and $0.5 \mathrm{~m}$ above the bottom), and the transparency (SD) was measured by Secchi disk at each site. The measurements of total phosphorus (TP), total nitrogen (TN), ammonia nitrogen $\left(\mathrm{NH}_{3}-\mathrm{N}\right)$, potassium permanganate $\left(\mathrm{COD}_{\mathrm{Mn}}\right)$ and fluoride $(\mathrm{F})$ were carried out with reference to Chinese EPA methods for the monitoring and analysis of water and wastewater (Chinese EPA, 2002).

A Chinese surface water quality standard (Tab.1) was applied to help defining bioregional reference and impairment criteria for each site (Tab. 2).

\section{Metric selection and calibration}

Seventeen phytoplankton metrics and seventeen zooplankton metrics were selected for evaluation of the multi-metric index (Tabs. 3 and 4). Statistical analyses for screening candidate metrics were performed with SPSS version 13.0 (SPSS Inc., Chicago, IL, USA). The metrics were calculated based on the sampling results of September. A stepwise process based on US EPA technical guidance (US EPA, 1998) for establishing biocriteria for lakes and reservoirs was used to evaluate the metrics for use in a multi-metric index. Three characteristics were evaluated for each metric: 1) discriminatory power, 2) redundancy, and 3) scoring of metrics.

\section{Discriminatory power}

We defined discriminatory power of a metric as the ability of that metric to distinguish between reference and impaired sites and evaluated metrics by examining their

Tab. 1. Five classes of surface water bodies (I-V) of water environmental quality standards (GB3838-2002) in China.

\begin{tabular}{|c|c|c|c|c|c|c|}
\hline \multirow[t]{2}{*}{ Indicators(mg/L) } & \multicolumn{6}{|c|}{ Classes } \\
\hline & & I & II & III & IV & $\mathbf{V}$ \\
\hline $\mathrm{TN}$ & $\leq$ & 0.2 & 0.5 & 1.0 & 1.5 & 2.0 \\
\hline $\mathrm{TP}$ (river) & $\leq$ & 0.02 & 0.1 & 0.2 & 0.3 & 0.4 \\
\hline $\mathrm{TP}$ (lake) and reservoirs) & $\leq$ & 0.01 & 0.025 & 0.05 & 0.1 & 0.2 \\
\hline $\mathrm{NH}_{3}-\mathrm{N}$ & $\leq$ & 0.15 & 0.5 & 1.0 & 1.5 & 2.0 \\
\hline $\mathrm{DO}$ & $\geq$ & $90 \%$ or 7.5 & 6 & 5 & 3 & 2 \\
\hline COD & $\leq$ & 15 & 15 & 20 & 30 & 40 \\
\hline $\mathrm{BOD}_{5}$ & $\leq$ & 3 & 3 & 4 & 6 & 10 \\
\hline $\mathrm{COD}_{\mathrm{Mn}}$ & $\leq$ & 2 & 4 & 6 & 10 & 15 \\
\hline
\end{tabular}

Tab. 2. Discriminatory factors for reference and impaired water.

\begin{tabular}{|c|c|c|c|c|c|}
\hline & $\rho(\mathrm{DO})$ & $\rho\left(\mathrm{COD}_{\mathrm{Mn}}\right)$ & $\begin{array}{c}\rho(\mathrm{TN}) \\
\mathrm{mg} / \mathrm{L}\end{array}$ & $\rho(\mathrm{TP})$ & $\rho\left(\mathrm{NH}_{3}-\mathrm{N}\right)$ \\
\hline Reference & $\geq 8.0$ & $\leq 6.0$ & $\leq 1.0$ & $\leq 0.05$ & $\leq 0.50$ \\
\hline Impaired & $<8.0$ & $>6.0$ & $>1.0$ & $>0.05$ & $>0.50$ \\
\hline
\end{tabular}

$\rho$, indicator concentration. 
distributions by using box-and-whisker plots. The degree of overlap between interquartile (IQ) ranges (the box) of reference and impaired sites was considered a signal of the discriminatory capability of the metric. Using the system developed by Barbour et al. (1996), metrics scoring 2 or 3 were retained for further analysis.

\section{Redundancy}

We evaluated redundancy among metrics to ensure that each metric in the final index provides new information. Using the remaining metrics, Pearson correlation coefficients was used to identify highly correlated metrics. A simple correlation alone is not

Tab. 3. Candidate biotic-metrics of algae.

\begin{tabular}{|c|c|c|c|}
\hline Category & Metrics and serial number & Response & Reference \\
\hline \multirow[t]{7}{*}{ Richness and abundance } & $\mathrm{P}_{1}$ : Relative abundance of diatoms (RAD) & Decrease & Griffith et al., 2005 \\
\hline & $\mathrm{P}_{2}:$ Algal cell abundance $(\mathrm{CA})$ & Decrease & \\
\hline & $\mathrm{P}_{3}:$ Margalef diversity index (Margalef) & Decrease & Margalef, 1958 \\
\hline & $\mathrm{P}_{4}:$ Shannon-Wiener diversity index (Shannon) & Decrease & Shannon, 1949 \\
\hline & $\mathrm{P}_{5}:$ Simpson diversity index (Simpson) & Decrease & Simpson, 1949 \\
\hline & $\mathrm{P}_{7}:$ Species richness $(\mathrm{SpR})$ & Decrease & Wu et al., 2012b \\
\hline & $\mathrm{P}_{8}:$ Chlorophyll a (Chla) & Increase & \\
\hline \multirow[t]{5}{*}{ Taxonomic composition } & $\mathrm{P}_{9}:$ Percent motile diatoms (PMD) & Increase & Bellinger et al., 2006 \\
\hline & $\mathrm{P}_{10}:$ Generic diatom index $(\mathrm{GI})$ & Decrease & Wu and Kow, 2002 \\
\hline & $\mathrm{P}_{11}:$ Diatom quotient (DQ) & Increase & Kane et al., 2009 \\
\hline & $\mathrm{P}_{13}: \%$ Cymbella $\mathrm{sp} .($ Cym.) & Decrease & Wang et al., 2005 \\
\hline & $\mathrm{P}_{14}: \%$ Navicula $\mathrm{sp} .($ Nav. $)$ & Increase & \\
\hline \multirow[t]{3}{*}{ Tolerance and intolerance index } & $\mathrm{P}_{15}:$ Pollution tolerance index for diatoms (PTI) & Decrease & Muscio, 2002 \\
\hline & $\mathrm{P}_{16}:$ Percent sensitive diatoms (PSD) & Decrease & Barbour et al., 1999 \\
\hline & $\mathrm{P}_{17}:$ Trophic diatom index (TDI) & Increase & Kelly and Whitton, 1995 \\
\hline
\end{tabular}

$P_{i}$, algae index.

Tab. 4. Candidate biotic-metrics of zooplankton.

\begin{tabular}{|c|c|c|c|}
\hline Category & Metrics and serial number & Response & Reference \\
\hline \multirow[t]{12}{*}{ Richness and abundance } & $\mathrm{Z}_{1}$ : Total zooplankton abundance (TZA) & Decrease & Carpenter et al., 2006 \\
\hline & $\mathrm{Z}_{2}$ : Biomass of zooplankton/biomass of phytoplankton $(\mathrm{Z} / \mathrm{P})$ & Decrease & Kane et al., 2009 \\
\hline & $Z_{3}:$ Taxa richness $(\mathrm{TAR})$ & Decrease & O'Connor et al., 2000 \\
\hline & $\mathrm{Z}_{4}$ : Calanodia abundance $(\mathrm{Cal})$. & Decrease & Carpenter et al., 2006Kane et al., 2009 \\
\hline & $Z_{5}:$ Rotifer abundance $($ Rot. $)$ & Decrease & \\
\hline & $\mathrm{Z}_{6}$ : Cladocera abundance $(\mathrm{Cla}$. $)$ & Decrease & Carpenter et al., 2006 \\
\hline & $\mathrm{Z}_{7}$ : Copepoda abundance (Cop.) & Decrease & \\
\hline & $Z_{8}:$ Copepod nauplii abundance (Cop. $n$ ) & Decrease & \\
\hline & $\mathrm{Z}_{9}:$ Cyclopoida abundance $(C y c)$. & Increase & \\
\hline & $\mathrm{Z}_{10}:$ Harpacticoida abundance (Har.) & Decrease & \\
\hline & $\mathrm{Z}_{11}:$ Zooplankton ratio $(\mathrm{ZR})$ & Decrease & Kane et al., 2009 \\
\hline & $\mathrm{Z}_{12}:$ Biomass of crustacean zooplankton $(\mathrm{CZ})$ & Increase & \\
\hline \multirow[t]{4}{*}{ Diversity } & $\mathrm{Z}_{13}:$ Margalef diversity index (Margalef) & Decrease & Margalef, 1958 \\
\hline & $Z_{14}:$ Shannon-Wiener diversity index (Shannon) & Decrease & Shannon, 1949 \\
\hline & $\mathrm{Z}_{15}:$ Simpson diversity index (Simpson) & Decrease & Simpson, 1949 \\
\hline & $\mathrm{Z}_{16}:$ Pieloud evenness index (Pieloud) & Decrease & Yang et al., 2011 \\
\hline Tolerance & $\mathrm{Z}_{17}:$ Wetland zooplankton index (WZI) & Decrease & Lougheed and Chow-Fraser, 2002 \\
\hline
\end{tabular}


considered sufficient to regard two metrics as redundant (US EPA, 1998). It is suggested that usually a tight correlation $(r>0.75)$ and a linear relationship is necessary to consider two metrics redundant. Pairs of metrics with lower correlation coefficients usually showed enough scatter or nonlinearity to indicate that each metric provided some new information. We selected one metric from each group of redundant metrics. We retained the one that had a tight correlation $(\mathrm{r}<0.75)$ for further analysis (Maxted et al., 2000).

\section{Scoring of metrics}

We used the $95^{\text {th }}$ or $5^{\text {th }}$ percentile value because this method avoids using anomalously high or low outliers as the best expected value (US EPA, 1999). The frequency was distributed at the reference sites of metrics $95^{\text {th }}$ percentile and the maximum value. Calculated metric values were converted (normalized) to metric scores of 5 , 3 or 1 depending on their proximity to the optimal values. For the metrics whose values decreased with the increase of stress (positive metrics), metric values above the $50^{\text {th }}$ percentile were scored as 5 , metric values between and including the $5^{\text {th }}$ and $50^{\text {th }}$ percentiles were scored as 3 , and all metric values below the $5^{\text {th }}$ percentile were scored as 1 . For the metrics whose values increased with the increase of stress (negative metrics), metric values below the $50^{\text {th }}$ percentile were scored as 5, metric values between and including the $50^{\text {th }}$ and $95^{\text {th }}$ percentiles were scored as 3 , and metric values above the 95th percentile were scored as 1 .

A final multi-metric index of biotic integrity was created by summing selected metrics of phytoplankton and zooplankton to establish the Planktonic Integrity Index (PII).

\section{Power and accuracy analysis}

To assess the ability of the PII to distinguish sites or conditions, we also used box-and-whisker plots to define discriminatory power of the PII to distinguish between reference and impaired sites. The degree of overlap between interquartile (IQ) ranges (the box) of reference and impaired sites was considered a signal of the discriminatory capability of the PII, which scoring 2 or 3 . We chose the data of September and October in 2013 to verify the accuracy of the PII.

\section{Relationship with stressors}

The PII index was also tested for significant relationships with potential stressors. The potential stressors included limnological variables, such as WT, $\mathrm{pH}$, $\mathrm{SD}, \mathrm{EC}, \mathrm{DO}, \mathrm{TP}, \mathrm{TN}, \mathrm{NH}_{3}-\mathrm{N}, \mathrm{COD}_{\mathrm{Mn}}$, and fluoride. Principal component analysis (PCA) with SPSS version 13.0 was used to choose the major potential stressors (value of PC >0.7) and Pearson correlation analysis was used to identify important stressor-metric relationships (Wang et al., 2012).

\section{RESULTS}

\section{Species composition of phytoplankton and zooplankton}

A total of 140 species of phytoplankton was obtained through sampling from 26 sites of Jingpo Lake: 58 species of Chlorophyta, 49 species of Bacillariophyta, 17 species of Cyanophyta, 8 species of Euglenophyta, 2 species of Pyrrophyta, Cryptophyta, Chrysophyta and Xanthophyta, respectively, accounting for $41.5 \%, 35.0 \%, 12.05 \%$, $5.7 \%, 1.4 \%, 1.4 \%, 1.4 \%$ and $1.4 \%$ of the total number of collected species, respectively.

A total of 92 species of zooplankton were obtained through sampling from 26 sites of Jingpo Lake: 46 species of Rotifer, 20 species of Protozoa, 16 species of Copepoda and 10 species of Cladocera, accounting for $50.0 \%$, $21.7 \%, 17.4 \%$ and $10.9 \%$ of the total number of collected species, respectively.

\section{Evaluation of metrics}

Following the water quality criteria (Type II and III) derived from Chinese surface water quality standard, 10 sites (S2, S4, S6, S7, S8, S9, S10, S12, S13 and S26) were determined as reference sites, the remained 16 sites were impaired sites. The information of water quality measures and characterization was shown in Tab. 5.

\section{Discriminatory power}

On the basis of this classification, of 17 phytoplankton metrics and 17 zooplankton metrics evaluated, 7 phytoplankton and 5 zooplankton metrics scored a 2 or 3 in discriminatory power between reference and impaired sections (Fig. 2). The 7 phytoplankton metrics were $\mathrm{P}_{2}$, $\mathrm{P}_{3}, \mathrm{P}_{4}, \mathrm{P}_{5}, \mathrm{P}_{6}, \mathrm{P}_{7}$ and $\mathrm{P}_{17}$, and the 5 zooplankton metrics were $Z_{1}, Z_{3}, Z_{5}, Z_{13}$ and $Z_{14}$.

\section{Redundancy}

Among the 7 phytoplankton metrics, several pairs or groups were highly correlated and considered redundant (Tab. 6), including $\mathrm{P}_{3}$ with $\mathrm{P}_{4}, \mathrm{P}_{5}$ and $\mathrm{P}_{7}($ all $r>0.75, \mathrm{P}<0.01$ ), $\mathrm{P}_{4}$ with $\mathrm{P}_{5}, \mathrm{P}_{6}$ and $\mathrm{P}_{7}($ all $r>0.75, \mathrm{P}<0.01), \mathrm{P}_{5}$ with $\mathrm{P}_{6}(r=$ $0.954, \mathrm{P} 0.01)$. Finally we selected $\mathrm{P}_{7}$ from the three groups of redundant metrics, because it was simpler to calculate than the other metrics. The two other metrics $\left(\mathrm{P}_{2}\right.$ and $\left.\mathrm{P}_{17}\right)$ that were not redundant with any other metrics were also candidates for final selection, leaving a total of three algae metrics for establishing the PII. Among the 5 zooplankton metrics, several pairs or groups were highly correlated and considered redundant (Tab. 7), including $Z_{1}$ with $Z_{3}$ and $Z_{5}$ 
(all $r>0.75, \mathrm{P}<0.01), \mathrm{Z}_{3}$ with $\mathrm{Z}_{13}(r=0.824, \mathrm{P}<0.01)$. Finally we selected $Z_{13}$ from the two groups of redundant metrics. $\mathrm{Z}_{14}$, which was not redundant with any other metrics, was also a candidate for final selection, leaving a total of 2 zooplankton metrics for establishing the PII. Final metrics we selected were: Algal cell abundance, Species richness of algae, Trophic diatom index, Zooplankton Shannon index and Zooplankton Margalef index.

\section{Scoring of metrics}

Frequency distribution statistics and scoring criteria allowed us to select 5 metrics for our index (Tab. 8). Based on the scoring of each metric, a multi-metric on a scale ranging from 1 to 25 for bioassessment was developed for each site by addition of the 5 metrics. Four levels of discriminatory biocriteria for water quality were eventually obtained by quartation: $5-10$, very poor; $11-15$, poor; 16-20, fair; 21-25, good.

\section{Power and accuracy analysis}

As the results show that the PII can effectively distinguish between reference and impaired sites with no overlap between interquartile (IQ) ranges (the box) in September or October (Fig. 3), which indicated that the available power and accuracy of the PII.

\section{Relationship to stressors}

The results of principal component analysis showed that WT, pH, EC, SD, DO, $\mathrm{COD}_{\mathrm{Mn}}, \mathrm{TN}, \mathrm{TP}$ and $\mathrm{NH}_{3}-\mathrm{N}$ were the main factors influencing the water quality of Jingpo Lake (Tab. 9).

The results of correlation between PII and main factors indicated that the PII scores were influenced more significantly in October $(R=-0.527, \mathrm{P}<0.01)$ than in September $(R=-0.420, \mathrm{P}<0.05)$ by WT, more significantly in September $(R=-0.534, \mathrm{P}<0.01)$ than in October

Tab. 5. Water quality of sampling sites in Jingpo Lake.

\begin{tabular}{|c|c|c|c|c|c|c|c|c|c|c|}
\hline Sites & $\mathrm{T}^{\circ} \mathrm{C}$ & $\mathrm{pH}$ & SD (m) & $\rho(\mathrm{EC})(\mathrm{ms} / \mathrm{m})$ & $\begin{array}{l}\rho(\mathrm{DO}) \\
(\mathrm{mg} / \mathrm{L})\end{array}$ & $\rho($ CODMn $)$ & $\rho(\mathrm{TN})$ & $\rho(\mathrm{TP})$ & $\rho(\mathbf{N H 3}-\mathbf{N})$ & $\rho(F)$ \\
\hline S1 & $14.20 \pm 7.70$ & $7.82 \pm 0.45$ & $0.38 \pm 0.24$ & $0.70 \pm 0.41$ & $10.56 \pm 0.57$ & $5.60 \pm 1.04$ & $1.00 \pm 0.03$ & $0.08 \pm 0.00$ & $0.18 \pm 0.06$ & $0.14 \pm 0.01$ \\
\hline S2 & $13.97 \pm 6.79$ & $7.83 \pm 0.47$ & $0.23 \pm 0.06$ & $9.90 \pm 0.96$ & $12.51 \pm 0.81$ & $5.47 \pm 0.67$ & $0.80 \pm 0.09$ & $0.05 \pm 0.00$ & $0.19 \pm 0.08$ & $0.16 \pm 0.01$ \\
\hline S3 & $15.40 \pm 7.43$ & $7.70 \pm 0.35$ & $0.22 \pm 0.08$ & $12.57 \pm 3.11$ & $10.34 \pm 1.47$ & $6.00 \pm 1.08$ & $1.05 \pm 0.33$ & $0.12 \pm 0.01$ & $0.20 \pm 0.11$ & $0.21 \pm 0.05$ \\
\hline S4 & $12.07 \pm 6.45$ & $8.10 \pm 0.62$ & $0.33 \pm 0.15$ & $11.87 \pm 1.31$ & $13.31 \pm 0.37$ & $5.70 \pm 0.56$ & $0.85 \pm 0.23$ & $0.06 \pm 0.01$ & $0.17 \pm \mathbf{0 . 0 7}$ & $0.16 \pm 0.01$ \\
\hline S5 & $9.90 \pm 3.93$ & $7.43 \pm 0.12$ & $0.17 \pm 0.12$ & $3.47 \pm 5.31$ & $10.29 \pm 2.00$ & $5.77 \pm 0.71$ & $0.88 \pm 0.28$ & $0.07 \pm 0.01$ & $0.21 \pm 0.09$ & $0.18 \pm 0.04$ \\
\hline S6 & $14.90 \pm 3.94$ & $8.20 \pm 1.08$ & $0.41 \pm 0.29$ & $6.50 \pm 5.28$ & $12.17 \pm 2.98$ & $5.80 \pm 0.10$ & $0.77 \pm 0.11$ & $0.05 \pm 0.00$ & $0.20 \pm 0.08$ & $0.14 \pm 0.03$ \\
\hline S7 & $13.27 \pm 3.90$ & $7.77 \pm 0.32$ & $0.37 \pm 0.15$ & $5.13 \pm 4.10$ & $12.05 \pm 2.18$ & $5.47 \pm 0.76$ & $0.76 \pm 0.30$ & $0.05 \pm 0.01$ & $0.21 \pm 0.08$ & $0.14 \pm 0.01$ \\
\hline S8 & $14.30 \pm 4.59$ & $7.87 \pm 0.45$ & $0.27 \pm 0.06$ & $5.10 \pm 3.52$ & $11.02 \pm 2.14$ & $5.33 \pm 0.64$ & $0.85 \pm 0.14$ & $0.05 \pm 0.00$ & $0.25 \pm 0.07$ & $0.13 \pm 0.01$ \\
\hline S9 & $14.83 \pm 3.77$ & $7.90 \pm 0.50$ & $0.40 \pm 0.10$ & $5.47 \pm 3.78$ & $10.61 \pm 1.85$ & $5.20 \pm 1.22$ & $0.93 \pm 0.01$ & $0.05 \pm 0.01$ & $0.24 \pm 0.04$ & $0.18 \pm 0.02$ \\
\hline S10 & $15.47 \pm 2.60$ & $7.90 \pm 0.56$ & $0.35 \pm 0.23$ & $5.23 \pm 4.37$ & $10.40 \pm 0.00$ & $5.47 \pm 0.58$ & $0.92 \pm 0.08$ & $0.05 \pm 0.02$ & $0.21 \pm 0.09$ & $0.15 \pm 0.01$ \\
\hline $\mathrm{S} 11$ & $16.70 \pm 4.44$ & $7.63 \pm 0.29$ & $0.33 \pm 0.12$ & $8.37 \pm 0.32$ & $8.90 \pm 0.84$ & $6.17 \pm 1.37$ & $0.94 \pm 0.01$ & $0.07 \pm 0.02$ & $0.24 \pm 0.09$ & $0.16 \pm 0.02$ \\
\hline S12 & $16.37 \pm 2.56$ & $7.77 \pm 0.40$ & $0.32 \pm 0.16$ & $7.67 \pm 0.90$ & $10.44 \pm 3.03$ & $5.30 \pm 1.13$ & $0.68 \pm 0.28$ & $0.05 \pm 0.00$ & $0.22 \pm 0.13$ & $0.16 \pm 0.02$ \\
\hline S13 & $16.90 \pm 3.22$ & $7.87 \pm 0.51$ & $0.47 \pm 0.06$ & $5.93 \pm 4.71$ & $11.44 \pm 2.06$ & $5.07 \pm 1.36$ & $0.92 \pm 0.08$ & $0.05 \pm 0.01$ & $0.22 \pm 0.14$ & $0.14 \pm 0.01$ \\
\hline S14 & $16.30 \pm 2.30$ & $7.67 \pm 0.47$ & $0.47 \pm 0.06$ & $8.23 \pm 1.15$ & $8.10 \pm 0.71$ & $5.73 \pm 1.27$ & $1.12 \pm 0.34$ & $0.06 \pm 0.00$ & $0.22 \pm 0.14$ & $0.17 \pm 0.02$ \\
\hline $\mathrm{S} 15$ & $16.57 \pm 2.76$ & $7.70 \pm 0.36$ & $0.47 \pm 0.06$ & $8.30 \pm 0.60$ & $8.65 \pm 0.78$ & $5.93 \pm 1.51$ & $1.16 \pm 0.09$ & $0.06 \pm 0.00$ & $0.25 \pm 0.07$ & $0.18 \pm 0.02$ \\
\hline S16 & $16.73 \pm 2.06$ & $7.77 \pm 0.45$ & $0.47 \pm 0.12$ & $5.70 \pm 3.82$ & $9.00 \pm 1.44$ & $6.17 \pm 1.31$ & $1.01 \pm 0.06$ & $0.07 \pm 0.02$ & $0.21 \pm 0.08$ & $0.16 \pm 0.01$ \\
\hline S17 & $16.57 \pm 2.20$ & $7.87 \pm 0.49$ & $0.43 \pm 0.06$ & $8.20 \pm 0.46$ & $8.23 \pm 1.09$ & $5.90 \pm 1.23$ & $1.11 \pm 0.09$ & $0.07 \pm 0.02$ & $0.26 \pm 0.07$ & $0.14 \pm 0.02$ \\
\hline S18 & $16.67 \pm 2.21$ & $7.77 \pm 0.35$ & $0.43 \pm 0.06$ & $8.23 \pm 0.55$ & $7.86 \pm 0.57$ & $6.37 \pm 1.55$ & $0.90 \pm 0.04$ & $0.06 \pm 0.01$ & $0.28 \pm 0.06$ & $0.15 \pm 0.02$ \\
\hline S19 & $16.80 \pm 2.10$ & $7.80 \pm 0.40$ & $0.62 \pm 0.18$ & $8.00 \pm 0.46$ & $8.65 \pm 0.07$ & $6.50 \pm 1.66$ & $0.98 \pm 0.11$ & $0.05 \pm 0.00$ & $0.23 \pm 0.13$ & $0.19 \pm 0.03$ \\
\hline $\mathrm{S} 20$ & $16.97 \pm 1.88$ & $7.77 \pm 0.32$ & $0.67 \pm 0.13$ & $6.80 \pm 2.61$ & $8.23 \pm 0.89$ & $5.93 \pm 1.07$ & $0.96 \pm 0.09$ & $0.05 \pm 0.00$ & $0.27 \pm 0.09$ & $0.18 \pm 0.02$ \\
\hline $\mathrm{S} 21$ & $16.90 \pm 1.78$ & $7.93 \pm 0.50$ & $0.50 \pm 0.00$ & $7.90 \pm 0.35$ & $8.43 \pm 1.17$ & $6.20 \pm 1.61$ & $0.98 \pm 0.07$ & $0.06 \pm 0.00$ & $0.33 \pm 0.06$ & $0.16 \pm 0.01$ \\
\hline $\mathrm{S} 22$ & $16.63 \pm 2.22$ & $7.80 \pm 0.50$ & $0.87 \pm 0.12$ & $7.87 \pm 0.40$ & $7.93 \pm 0.88$ & $6.17 \pm 1.46$ & $1.01 \pm 0.04$ & $0.08 \pm 0.00$ & $0.41 \pm 0.08$ & $0.18 \pm 0.03$ \\
\hline $\mathrm{S} 23$ & $16.60 \pm 2.10$ & $7.90 \pm 0.56$ & $0.72 \pm 0.03$ & $8.77 \pm 0.86$ & $7.86 \pm 1.47$ & $6.20 \pm 1.39$ & $1.11 \pm 0.08$ & $0.07 \pm 0.01$ & $0.29 \pm 0.09$ & $0.14 \pm 0.01$ \\
\hline S24 & $16.50 \pm 2.25$ & $7.97 \pm 0.59$ & $0.57 \pm 0.06$ & $9.30 \pm 1.45$ & $8.13 \pm 0.01$ & $6.07 \pm 1.63$ & $1.16 \pm 0.06$ & $0.06 \pm 0.00$ & $0.25 \pm 0.06$ & $0.15 \pm 0.01$ \\
\hline $\mathrm{S} 25$ & $15.37 \pm 2.99$ & $7.97 \pm 0.59$ & $0.5 \pm 0.10$ & $7.10 \pm 1.22$ & $9.56 \pm 2.23$ & $6.33 \pm 1.59$ & $1.03 \pm 0.04$ & $0.07 \pm 0.01$ & $0.21 \pm 0.07$ & $0.17 \pm 0.01$ \\
\hline S26 & $13.90 \pm 7.20$ & $7.90 \pm 0.53$ & $0.57 \pm 0.06$ & $8.80 \pm 1.42$ & $13.33 \pm 3.01$ & $5.33 \pm 1.07$ & $0.60 \pm 0.02$ & $0.05 \pm 0.00$ & $0.19 \pm 0.10$ & $0.22 \pm 0.02$ \\
\hline
\end{tabular}

T, temperature; SD, transparency; EC, electrical conductivity; DO, dissolved oxygen; TP, total phosphorus; TN, total nitrogen; COD ${ }_{n}$, potassium permanganate; $\mathrm{NH}_{3}-\mathrm{N}$, ammonia nitrogen; $\mathrm{F}$, fluoride; $\rho$, indicator concentration. 
Tab. 6. Pearson correlation analysis of 7 algae candidate metrics.

\begin{tabular}{|c|c|c|c|c|c|c|c|}
\hline & $\mathbf{P}_{2}$ & $\mathbf{P}_{3}$ & $\mathbf{P}_{4}$ & $\mathbf{P}_{5}$ & $\mathbf{P}_{6}$ & $\mathbf{P}_{7}$ & $\mathbf{P}_{17}$ \\
\hline $\mathrm{P}_{2}$ & 1 & & & & & & \\
\hline $\mathrm{P}_{3}$ & $0.633^{* *}$ & 1 & & & & & \\
\hline $\mathrm{P}_{4}$ & $0.413^{*}$ & $0.868^{* *}$ & 1 & & & & \\
\hline $\mathrm{P}_{5}$ & 0.343 & $0.792 * *$ & $0.973 * *$ & 1 & & & \\
\hline $\mathrm{P}_{6}$ & 0.142 & $0.610^{* *}$ & $0.908^{* *}$ & $0.954 * *$ & 1 & & \\
\hline $\mathrm{P}_{7}$ & $0.746^{* *}$ & $0.982 * *$ & $0.805 * *$ & $0.712^{* *}$ & 0.510 & 1 & \\
\hline$P_{17}$ & 0.021 & -0.385 & -0.479 & -0.524 & -0.471 & -0.332 & 1 \\
\hline
\end{tabular}

$* P<0.05 ; * * P<0.01$.

Tab. 7. Pearson correlation analysis of 5 zooplankton candidate metrics.

\begin{tabular}{lccccc} 
& $Z_{1}$ & $Z_{3}$ & $Z_{5}$ & $Z_{13}$ & $Z_{14}$ \\
$Z_{1}$ & 1 & & & & \\
\hline$Z_{3}$ & $0.910^{* *}$ & 1 & & & \\
\hline$Z_{5}$ & $0.846^{* *}$ & $0.747^{* *}$ & 1 & 1 & \\
\hline$Z_{13}$ & 0.632 & $0.824^{* *}$ & $0.618^{* *}$ & 1 & \\
\hline$Z_{14}$ & $0.539^{* *}$ & $0.730^{* *}$ & $0.442^{*}$ & $0.710^{* *}$ & 1 \\
\hline$* P<0.05 * * *<<0.01$ & & & & &
\end{tabular}
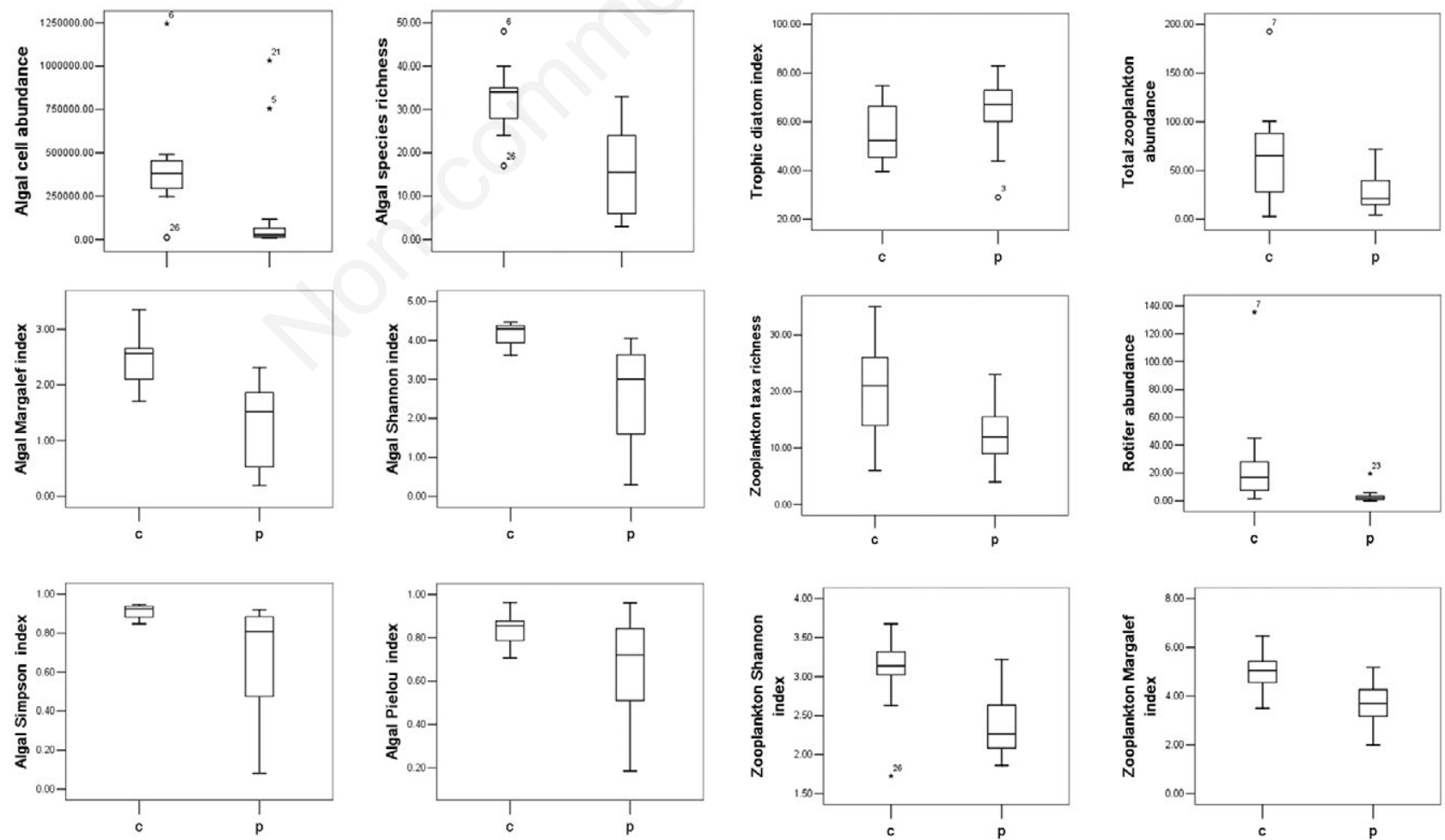

Fig. 2. Discriminatory of algae and zooplankton metrics by box-and-whisker plots. The degree of overlap between interquartile (IQ) ranges (the box) of reference and impaired sites was considered a signal of the discriminatory capability of the PII, which scoring 2 or 3 , in this study, the metrics with IQ $\geq 2$ could go to the next screening steps. c, reference sites; p: impaired sites. 
Tab. 8. Frequency distribution statistics of the final metrics and associated scoring criteria.

\begin{tabular}{|c|c|c|c|c|c|c|c|c|}
\hline \multirow[t]{2}{*}{ Metrics } & \multicolumn{5}{|c|}{ Frequency distribution } & \multicolumn{3}{|c|}{ Score } \\
\hline & Min & $\begin{array}{c}5^{\text {th }} \\
\text { percentile }\end{array}$ & $\begin{array}{c}50^{\text {th }} \\
\text { percentile }\end{array}$ & $\begin{array}{c}95^{\text {th }} \\
\text { percentile }\end{array}$ & Max & 5 & 3 & 1 \\
\hline Algal cell abundance $\left(\times 10^{4}\right)$ & 0.75 & 0.87 & 6.53 & 117.04 & 124.5 & $>6.53$ & $0.87 \sim 6.53$ & $<0.87$ \\
\hline Species richness of algae & 3 & 3 & 23 & 45.2 & 48 & $>23$ & $3 \sim 23$ & $<3$ \\
\hline Trophic diatom index & 28.97 & 32.68 & 63.47 & 80.17 & 82.95 & $<63.47$ & $63.47 \sim 80.17$ & $>80.17$ \\
\hline Zooplankton Shannon index & 1.72 & 1.77 & 2.61 & 3.59 & 3.68 & $>2.61$ & $1.77 \sim 2.61$ & $<1.77$ \\
\hline Zooplankton Margalef index & 1.99 & 2.13 & 4.26 & 6.15 & 6.46 & $>4.26$ & $2.13 \sim 4.26$ & $<2.13$ \\
\hline
\end{tabular}

Tab. 9. Rotated component matrix.

\begin{tabular}{|c|c|c|c|c|c|c|c|}
\hline \multirow[t]{2}{*}{ Factors } & \multicolumn{4}{|c|}{ September } & \multicolumn{3}{|c|}{ October } \\
\hline & PC1 & $\mathrm{PC} 2$ & $\mathrm{PC} 3$ & PC4 & PC1 & $\mathrm{PC} 2$ & $\mathrm{PC} 3$ \\
\hline WT & 0.71 & 0.55 & -0.18 & 0.04 & 0.91 & 0.29 & -0.03 \\
\hline $\mathrm{DO}$ & 0.80 & 0.36 & -0.28 & -0.25 & 0.88 & 0.13 & -0.12 \\
\hline $\mathrm{pH}$ & -0.00 & -0.12 & -0.00 & -0.97 & 0.08 & 0.03 & 0.92 \\
\hline $\mathrm{EC}$ & -0.10 & -0.36 & 0.82 & -0.22 & -0.47 & -0.18 & 0.73 \\
\hline $\mathrm{COD}_{\mathrm{Mn}}$ & 0.74 & 0.13 & -0.28 & 0.11 & 0.82 & -0.10 & -0.06 \\
\hline $\mathrm{TN}$ & 0.18 & 0.91 & 0.03 & -0.16 & 0.71 & -0.13 & 0.29 \\
\hline $\mathrm{TP}$ & -0.12 & 0.38 & 0.83 & 0.24 & -0.18 & -0.80 & -0.15 \\
\hline $\mathrm{NH}_{3}-\mathrm{N}$ & 0.85 & 0.23 & 0.03 & -0.19 & -0.10 & 0.74 & -0.23 \\
\hline Characteristic value & 3.13 & 1.70 & 1.58 & 1.22 & 3.73 & 1.35 & 1.31 \\
\hline Cumulative variance $\%$ & 34.8 & 53.7 & 71.2 & 84.7 & 41.4 & 56.4 & 71.0 \\
\hline
\end{tabular}
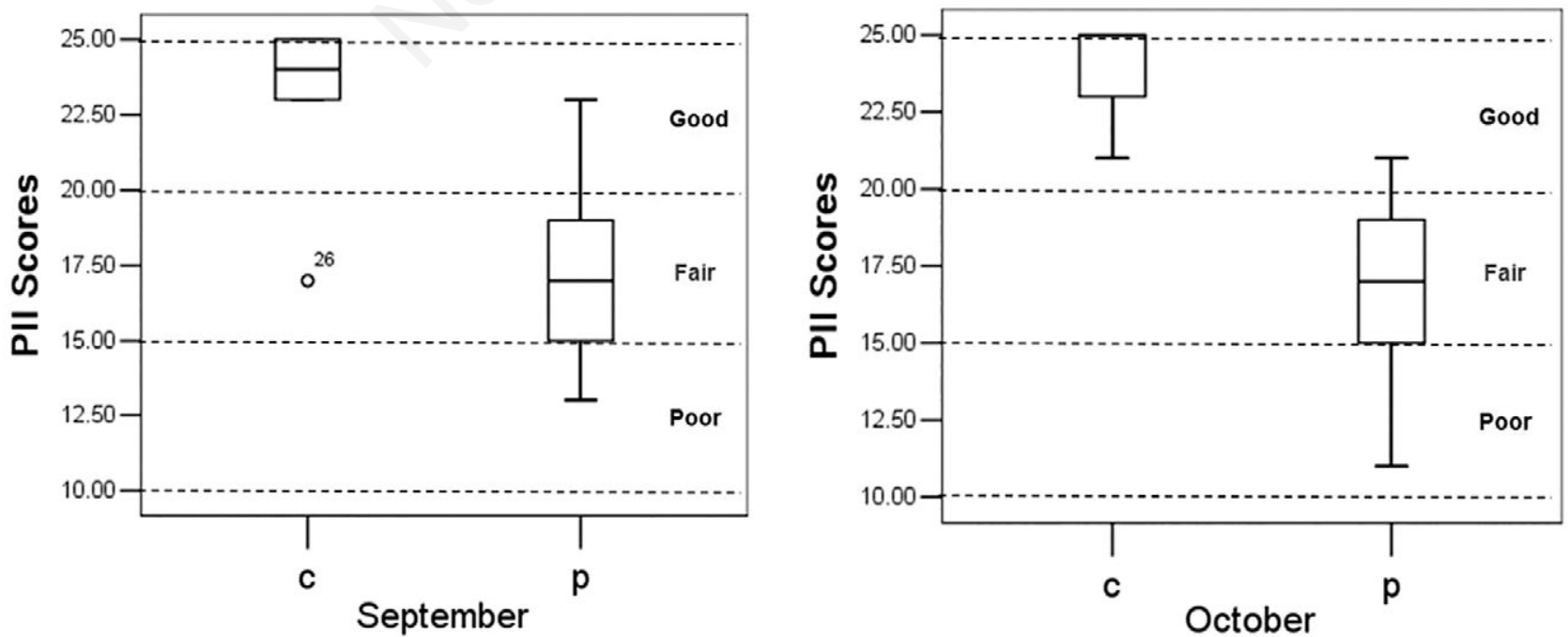

Fig. 3. Distinguish efficiency of PII in September and October. c, clean sites; p: impaired sites. 
$(R=-0.461, \mathrm{P}<0.05)$ by $\mathrm{SD}$, significantly in September $(R=0.588, \mathrm{P}<0.01)$ and October $(R=0.559, \mathrm{P}<0.01)$ by DO, significantly in September $(R=-0.581, \mathrm{P}<0.01)$ and October $(R=-0.587, \mathrm{P}<0.01)$ by $\mathrm{COD}_{\mathrm{Mn}}$, significantly in October $(R=-0.432, \mathrm{P}<0.05)$ but not significantly in September $(R=-0.300, \mathrm{P}>0.05)$ by TN, and the other factors $\left(\mathrm{pH}, \mathrm{EC}, \mathrm{TP}\right.$ and $\mathrm{NH}_{3}-\mathrm{N}$ ) had no significant correlations with the PII scores (Fig. 4).

\section{DISCUSSION}

\section{Selection of metrics and reference sites}

The reference condition approach (RCA) has recently emerged as a broadly applicable protocol to monitor quality of streams, rivers, and lakes at regional level (Tall et al., 2008). Usually, it is difficult to define the actual clean site (or reference site) in a homogeneous ecological region owing to frequent occurrence of pollution in freshwater bodies of China. So in this study, the classification of clean and impaired sites was only a relative division. Generally, there are two methods including Shannon-Wiener species diversity index method (Huang et al., 1982; Wang and Yang, 2003), and physico-chemical index method (Stribling et al., 1998), through which the reference and impaired sites can be differentiated. The physicochemical index method is undoubtedly more powerful, but it needs too many physicochemical indices for classification, and further leads to time consuming calculation and analysis. Only simple calculation is needed when Shannon-Wiener species diversity index method is employed; however, it has a low accuracy or some misjudgments because of limitation of sampling area (small area of the grab). Finally, we chose physicochemical index method for classification of clean and impaired sites.
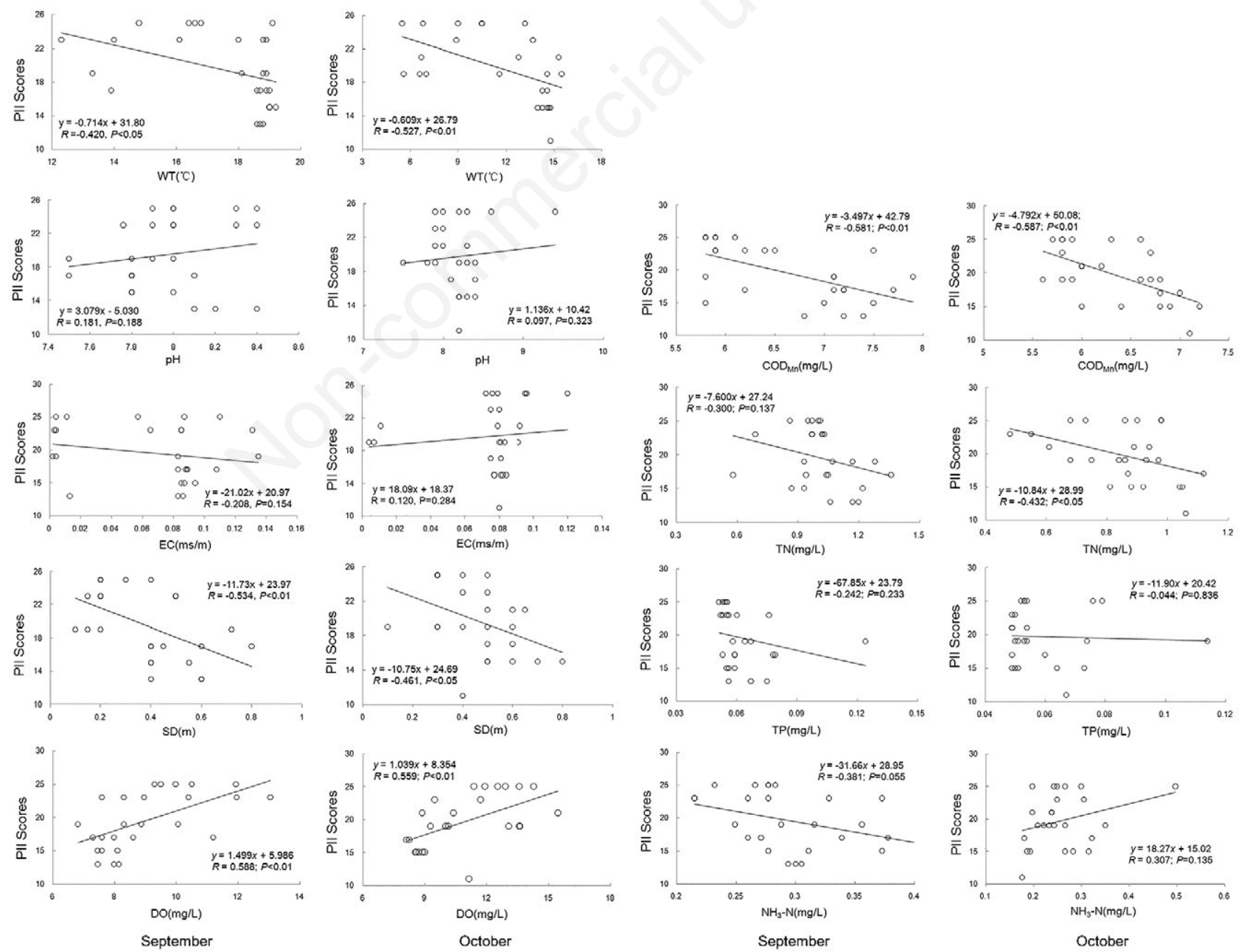

Fig. 4. The relationship between PII Scores and major environment factors. 


\section{Power and accuracy of the PII}

Discriminatory power of a metric is defined as the ability of that metric to distinguish between reference and impaired sites and the metric needs to be evaluated by examining its distribution by using box-and-whisker plots. In this study, the reference and impaired sites could be effectively distinguished by the PII with no overlap between IQ ranges (the box) in September or October (Fig. 3 ), which indicated the available power and accuracy of the PII. Additionally, the bioassessment results of Jingpo Lake by PII indicated that the water quality of upstream region was better than central and outlet of Jingpo Lake, which was completely consistent with previous studies assessed by Algal cell abundance, Species richness of algae, Phytoplankton Shannon index, Phytoplankton Margalef index, Species richness of zooplankton, Zooplankton Shannon index and Zooplankton Margalef index, respectively (Yu et al., 2008a; Song and Yu, 2009; Liu et al., 2012; Wang et al., 2015a, 2015b).

However, the factors of habitat, hydrology, physics and chemistry, human activities, for example, flow velocity, climate, land use, man-made dams, cultivation, deforestation, which can influence the power and accuracy of the assessment results were not yet considered into the PII. So the PII with comprehensive assessment systems needs to be established, so as to improve the power and accuracy of the assessment metric established in our present study.

\section{Relationship between PII and environment factors}

WT (Mageed and Heikal, 2006; Jiang et al., 2014), SD (Arhonditsis et al., 2004; Dejen et al., 2004; Wang et al., 2015b), pH (Wu et al., 2011), $\mathrm{COD}_{\mathrm{Mn}}, \mathrm{TN}, \mathrm{NH}_{3}-$ $\mathrm{N}$ (Yu et al., 2008a; Yang et al., 2012; Wang et al., 2015a, 2015b), DO, TP, Chl a (Wu et al., 2011; Wang et al., 2012; Jiang et al., 2014), chloride, orthophosphate and silica (Swadling et al., 2000; Jiang et al. 2014) can all become the major factors influencing the community composition of phytoplankton and zooplankton. As our results show, WT, $\mathrm{SD}, \mathrm{DO}, \mathrm{COD}_{\mathrm{Mn}}$ and $\mathrm{TN}$ were the major factors influencing PII, indicating that these five environmental parameters were also the limiting factors influencing the community distribution of phytoplankton and zooplankton in Jingpo Lake. As a cold lake in the northeastern of China, the water temperature showed significantly differences in day and night and different seasons in Jingpo Lake, which may affect the composition of phytoplankton and zooplankton (Liu and Xu, 1996; Yu et al., 2008a; Wang et al., 2015a, 2015b). Phytoplankton need light for photosynthesis and oxygen for respiration, which indicated that $\mathrm{SD}$ is one key factors for phytoplankton growth (Wang et al., 2015b).
Likewise, the growth of zooplankton needs not only requisite ingestion of algae, but also oxygen (DO) for respiration, which is rather a response parameter to photosynthesis (indicator, response parameter) and secondary production, than a major (affective) parameter for primary production (Wang et al., 2015b). $\mathrm{COD}_{\mathrm{Mn}}$ and $\mathrm{TN}$ are usually used for monitoring of the point and nonpoint pollution. As shown in some studies, the external contaminations of Jingpo Lake mainly came from the industrial and domestic wastewater of Dunhua City, located upstream of Jingpo Lake. Agricultural fertilizer entered via runoff into Jingpo Lake and domestic wastewater and landfill leachate also entered Jingpo Lake. Thus $\mathrm{COD}_{\mathrm{Mn}}$ was mainly affected by industrial wastewater, whereas $\mathrm{TN}$ was mainly affected by domestic wastewater and agricultural fertilizer (Jin et al., 2009; Li, 2013). The results of this study also indicated that point and nonpoint pollution may be the direct factors influencing on composition and distribution of phytoplankton and zooplankton in Jingpo Lake.

\section{CONCLUSIONS}

In the present study, a Planktonic Integrity Index (PII) for the China's largest alpine barrier lake (Jingpo Lake) was developed to assess the water quality of Jingpo Lake by using phytoplankton and zooplankton metrics. A total of 140 species of phytoplankton and 92 species of zooplankton were obtained in the investigations. Algal cell abundance, Species richness of algae, Trophic diatom index, Zooplankton Shannon index, and Zooplankton Margalef index were selected for the PII. Evaluation of the PII showed that it discriminated well between reference and impaired sites and the discriminatory biocriteria of the PII were suitable for the assessment of the water quality of Jingpo Lake. The further scoring results from the 26 sites showed that the water quality of Jingpo Lake was fair to good. Additionally, more metrics belonging to habitat, hydrology, physics and chemistry should also be considered into the PII, so as to establish comprehensive assessment system which can reflect the community structure of aquatic organisms, physical and chemical characteristics of water environment and, human activities.

\section{ACKNOWLEDGMENTS}

This study was financially supported by The National Major Project of Water Pollution Control and Prevention Technology (2018ZX07208-008). The Authors wish to thank Li Li, Zhuang Daokuo for their valuable sampling and experimental assistance. 


\section{REFERENCES}

Angermeier PL, Smogor RA, Stauffer JR, 2000. Regional frameworks and candidate metrics for assessing biotic integrity in mid-Atlantic highland streams. T. Am. Fish. Soc. 129:962-981.

Arhonditsis GB, Winder M, Brett MT, Schindler DE, 2004. Patterns and mechanisms of phytoplankton variability in Lake Washington (USA). Water Res. 38:4013-4027.

Barbour MT, Gerritsen J, Griffith GE, Frydenborg R, McCarron E, White JS, Bastian ML, 1996. A framework for biological criteria for Florida streams using benthic macroinvertebrates. J. N. Am. Benthol. Soc. 15:185-211.

Barbour MT, Gerritsen J, Snyder B D, Stribling JB, 1999. Rapid bioassessment protocols for use in streams and wadeable rivers. US EPA, Washington.

Bellinger BJ, Cocquyt C, O'Reilly C M, 2006. Benthic diatoms as indicators of eutrophication in tropical streams. Hydrobiologia 573:75-87.

Blocksom KA, Kuptenbach JP, Klemm DJ, Fulk FA, Cormier SM, 2002. Development and evaluation of the lake macroinvertebrate integrity index (LMII) for new Jersey lakes and reservoirs. Environ. Monit. Assess. 77:311-333.

Carpenter K E, Johnson J M, Buchanan C, 2006. An index of biotic integrity based on the summer polyhaline zooplankton community of the Chesapeake Bay. Mar. Environ. Res. 62:165-180.

Chinese EPA, 2002. Methods for the monitoring and analysis of water and wastewater. Chinese Environmental Science Press, Beijing.

Chen LQ, Wang YL, Wang QX, Bao WM. 1994. [Evaluation of Jingpo Lake phytoplankton and water quality].[Article in Chinese]. Natural Sci. Harbin Normal University 10:80-84.

Chon TS, Qu XD, Cho WS, Hwang HJ, Tang HQ, Liu YD, Choi JH, Jung M, Chung BS, Lee HY, 2013. Evaluation of stream ecosystem health and species association based on multitaxa (benthic macroinvertebrates, algae, and microorganisms) patterning with different levels of pollution. Ecol. Inform. 17:58-72.

Dejen E, Vijverberg J, Nagelkerke LAJ, Sibbing FA, 2004. Temporal and spatial distribution of microcrustacean zooplankton in relation to turbidity and other environmental factors in a large tropical lake (L. Tana, Ethiopia). Hydrobiologia 513:39-49.

Echaniz SA, Vignatti AM, de Paggi SJ, Paggi JC, Pilati A, 2006. Zooplankton seasonal abundance of south American saline shallow lakes. Int. Rev. Hydrobiol. 91:86-100.

Griffith MB, Hill BH, McCormick FH, Kaufmann PR, Herlihy AT, Selle AR, 2005. Comparative application of indices of biotic integrity based on periphyton, macroinvertebrates, and fish to southern Rocky Mountain streams. Ecol. Indic. 5:117-136.

Hill BH, Herlihy AT, Kaufmann PR, DeCelles SJ, Vander Borgh MA, 2003. Assessment of streams of the eastern United States using a periphyton index of biotic integrity. Ecol. Indic. 2:325-338.

Huang YY, Teng DX, Zhao ZX, 1982. [Monitoring Jiyunhe estuary pollution by use of macroinvertebrate community and diversity index].[Article in Chinese]. Sinozool. 2:133-146.

Jiang Y, Xu H, Zhang W, Zhu M, AI-Rasheid KAS, 2012. Can body-size patterns of ciliated zooplankton be used for assessing marine water quality? A case study on bioassessment in Jiaozhou Bay, northern Yellow Sea. Environ. Sci. Pollut. 19:1747-1754.

Jiang YJ, He W, Liu WX, Qin N, Ouyang HL, Wang QM, Kong XZ, He QS, Yang C, Yang B, Xu FL, 2014. The seasonal and spatial variations of phytoplankton community and their correlation with environmental factors in a large eutrophic Chinese lake (Lake Chaohu). Ecol. Indic. 40:58-67.

Jin ZM, Yang CW, Jin JL, Liu C, 2009. [A status investigation of water quality and eutrophication in Jingpo Lake].[Article in Chinese]. Water Resour. Prot. 25:56-58.

Kane DD, Gordon SI, Munawar M, Charlton MN, Culver DA, 2009. The Planktonic Index of Biotic Integrity (P-IBI): An approach for assessing lake ecosystem health. Ecol. Indic. 9: 1234-1247.

Kelly MG, Whitton BA, 1995. The Trophic Diatom Index: a new index for monitoring eutrophication in rivers. J. Appl. Phycol. 7:433-444.

Kerans BL, Karr JR, 1994. A benthic index of biotic integrity (BIBI) for rivers of the Tennessee Valley. Ecol. Appl. 4:768-785.

Klemm DJ, Blocksom KA, Fulk FA, Herlihy AT, Hughes RM, Kaufmann PR, Peck DV, Stoddard JL, Thoeny WT, Griffith MB, Davis WS, 2003. Development and evaluation of a macroinvertebrate biotic integrity index (MBII) for regionally assessing mid-Atlantic highlands streams. Environ. Manage. 31:656-669.

Li SQ, 2013. [Analysis and evaluation of water quality of the Jingpo Lake].[Article in Chinese]. Heilongjiang Environ. J. 37:88-90.

Liu HY, Xu YL, 1996. Preliminary observation of algal growth and lake eutrophication in Jingpo Lake. Acta Ecologica Sinica. 16: 195-201.

Liu Y, Zhou X, Hou B, Luo Y, 2012. [Analysis of phytoplankton in Jingpo Lake].[Article in Chinese]. J. Eng. Heilongjiang Univ. 3:20-24.

Lougheed VL, Chow-Fraser P, 2002. Development and use of a zooplankton index of wetland quality in the Laurentian Great Lakes basin. Ecol. Appl. 12:474-486.

Lugoli F, Garmendia M, Lehtinen S, Kauppila P, Moncheva S, Revilla M, Roselli L, Slabakova N, Valencia V, Dromph KM, Basset A, 2012. Application of a new multi-metric phytoplankton index to the assessment of ecological status in marine and transitional waters. Ecol. Indic. 23:338-355.

Mageed AAA, Heikal MT, 2006. Factors affecting seasonal patterns in epilimnion zooplankton community in one of the largest man-made lakes in Africa (Lake Nasser, Egypt). Limnologica 36:91-97.

Margalef R, 1958. Information theory in ecology. Gen. Syst. 3:36-71.

Maxted JR, Barbour MT, Gerritsen J, Poretti V, Primrose N, Silvia A, Penrose D, Renfrow R, 2000. Assessment framework for mid-Atlantic coastal plain streams using benthic macroinvertebrates. J. N. Am. Benthol. Soc. 19:128-144.

McCormick FH, Hughes RM, Kaufmann PR, Peck DV, Stoddard JL, Herlihy AT, 2001. Development of an index of biotic integrity for the mid-Atlantic highlands streams. T. Am. Fish. Soc. 130:857-877.

Miller SJ, Wardrop DH, Mahaney WM, Brooks RP, 2006. A plant-based index of biological integrity (IBI) for headwater 
wetlands in central Pennsylvania. Ecol. Indic. 6:290-312.

Muscio C, 2002. The diatom pollution tolerance index: assigning tolerance values. Watershed Protection \& Development Review Department, Austin

O’Connor RJ, Walls TE, Hughes RM, 2000. Using multiple taxonomic groups to index the ecological condition of lakes. Environ. Monit. Assess. 61:207-228.

Shannon CE, Weaver W, 1949. The mathematical theory of communication. University of Illinois Press, Urbana.

Simpson EH, 1949. Measurement of diversity. Nature 163:688

Song C, Yu H, 2009. [Phytoplankton diversity in Jingpo Lake and water quality evaluation].[Article in Chinese]. J. Northeast. For. Univ. 4:40-42.

Stribling JB, Jessup BK, White JS, 1998. Chesapeake Bay and watershed programs (monitoring and non-tidal assessment): Development of a benthic index of biotic integrity for Maryland streams. Report NO. CBWP-MANTA-EA-98-3. Annapolis, MD: Maryland Department of Natural Resources, Maryland, 1-38.

Swadling KM, Pienitz R, Nogrady T, 2000. Zooplankton community composition of lakes in the Yukon and Northwest Territories (Canada): relationship to physical and chemical limnology. Hydrobiol. 431: 211-224.

Tall L, Methot G, Armellin A, Pinel-Alloul B, 2008. Bioassessment of benthic macroinvertebrates in wetland habitats of Lake Saint-Pierre (St. Lawrence River). J. Great Lakes Res. 34: 599-614.

US EPA, 1998. Lake and reservoir bioassessment and biocriteria: Technical guidance document, EPA 841-B-98007, US EPA, Washington.

US EPA, 1999. Rapid bioassessment protocols for use in wadeable streams and rivers, EPA 841B-99-002, US EPA, Washington.

Wang BX, Yang LF, 2003. [Bioassessment of Qinhuai River using a river biological index].[Article in Chinese]. Acta Ecol. Sin. 23: 2082-2091.

Wang X, Liu L, Li L, Wang Y, Zhou J, Xia F, 2015a. [Community structure of zooplankton and the relationship with environment factors in Jingpo Lake].[Article in Chinese]. China Sci. Technol. Achi. 16:22-27.

Wang X, Liu L, Li L, Zhou J, Wang Y, Xia F, Xia Y, 2015b. [Correlation analysis of algae composition and environmental factors in Jingpo Lake].[Article in Chinese]. China Environ. Sci. 35:3403-3413.

Wang X, Zheng BH, Liu LS, Li LQ, Huang DZ, Tian Q, 2012. [Canonical correspondence analysis of algae composition and its environmental factors of typical sections in Dongting Lake, China].[Article in Chinese]. J. Agro-Environ. Sci. 31:995-1002.

Wang X, Zheng BH, Liu LS, Wang LJ, 2015c. Development and evaluation of the Lake Multi-biotic Integrity Index for Dongting Lake, China. J. Limnol. 74:594-605.

Wang YK, Stevenson RJ, Metzmeier L, 2005. Development and evaluation of a diatom-based Index of Biotic Integrity for the Interior Plateau Ecoregion, USA. J. N. Am. Benthol. Soc. 24:990-1008.

Whittier TR, Hughes RM, Stoddard JL, Lomnicky GA, Peck DV, Herlihy AT, 2007. A structured approach for developing indices of biotic integrity: three examples from streams and rivers in the Western USA. T. Am. Fish. Soc. 136:718-735.

Wilcox DA, Meeker JE, Hudson PL, Armitage BJ, Black MG, Uzarski DG, 2002. Hydrologic variability and the application of index of biotic integrity metrics to wetlands: A great lakes evaluation. Wetlands 22:588-615.

Wu JT, Kow LT, 2002. Applicability of ageneric index for diatom assemblages to monitor pollution in the tropical River Tsanwun, Taiwan. J. Appl. Phycol. 14 63-69.

Wu L, Feng WS, Zhang T, Xu HJ, Yu YH, 2011. [The annual fluctuation of zooplankton community and its relation with environmental factors in Lake Xiliang, Hubei Province].[Article in Chinese]. J. Lake Sci. 23:619-625.

Wu NC, Cai QH, Fohrer N, 2012a. Development and evaluation of a diatom-based index of biotic integrity (D-IBI) for rivers impacted by run-of-river dams. Ecol. Indic. 18: 108-117.

Wu NC, Schmalz B, Fohrer N, 2012b. Development and testing of a phytoplankton index of biotic integrity (P-IBI) for a German lowland river. Ecol. Indic. 13:158-167.

Yang GJ, Qin BQ, Tang XM, Gong ZJ, Zhong CL, Zhou H, Wang XD, 2012. Contrasting zooplankton communities of two bays of the large, shallow, eutrophic Lake Taihu, China: Their relationship to environmental factors. J Great Lakes Res. 38:299-308.

Yang H, Wu M, Liu W, Zhang Z, Zhang N, Wan S, 2011. Community structure and composition in response to climate change in a temperate steppe. Global Change Biol. $17: 452-465$

Yoder CO, Rankin ET, 1995. Biological criteria program development and implementation in Ohio, p. 109-144. In: W.S. Davis and T.P. Simon (eds.), Biological assessment and criteria. Lewis Publ., Boca Raton.

Yu HX, Qu C, Ma CX, 2008a. [Correlation between phytoplankton abundance and its environmental factors in Mudan River].[Article in Chinese]. Wetl. Sci. 6:293-297.

Yu H, Wang Y, Ma C, Zuo Y, 2008b. [Community structure of crustacean zooplankton in Jingpo Lake].[Article in Chinese]. J. Northeast. For. Univ. 1:66-68.

Zalack JT, Smucker NJ, Vis ML, 2010. Development of a diatom index of biotic integrity for acid mine drainage impacted streams. Ecol. Indic. 10:287-295. 